\title{
PENGARUH KUALITAS PRODUK DAN KUALITAS LAYANAN TERHADAP KEPUASAN PELANGGAN DALAM MENGGUNAKAN JASA BUILDING AUTOMATIC SYSTEM PT. AZBIL BERCA INDONESIA
}

\author{
Tiarah ${ }^{1)}$ \\ 1) Mahasiswa Program Studi Manajemen FE UNKRIS \\ Nuridin ${ }^{2)}$ \\ 2) Dosen Program Studi Manajemen FE UNKRIS \\ Alamat: Kampus UNKRIS, Jatiwaringin Jakarta Timur \\ Email : h.nuridin58@gmail.com
}

\begin{abstract}
Abstrak: Abstrak: The research objective was to determine the effect of product quality and service quality on customer satisfaction in using Building Automatic System services at PT. Azbil Berca Indonesia. The analytical method was used, is quantitative analysis, with using test instruments, coefficient of determination, and multiple linear regression analysis. Simultaneously test of product quality variables and service quality on customer satisfaction in using Building Automatic System services at PT. Azbil Berca Indonesia, was indicated by $F$ count is bigger than $F$ table or with sig. prob is smaller than 0.05. Considering these results, the hypothesis Ho is rejected, Ha is accepted, which mean there is a simultaneously effect of product quality and service quality on customer satisfaction in using Building Automatic System services at PT. Azbil Berca Indonesia
\end{abstract}

Keywords: Product quality and service quality and customer satisfaction

\section{PENDAHULUAN}

Di era saat ini perusahaan sangat dituntut untuk meningkatkan kretifitas yang tinggi agar dapat bersaing di dalam persaingan bisnis yang sangat ketat. Salah satu kreatifitas perusahaan yang sangat penting adalah bagaimana produk dapat dipasarkan dengan tepat sasaran dan layanan yang diberikan sangat memuaskan pelanggan sehingga dapat menarik minat pelanggan.

Dewasa ini diyakini bahwa kunci utama untuk memenangkan persaingan adalah memberikan nilai dan kepuasan kepada pelanggan melalui penyampaian produk dan jasa berkualitas dengan layanan yang baik. Dengan terciptanya kepuasan pelanggan akan memberikan manfaat yang berarti bagi perusahaan yaitu hubungan antara perusahaan dengan pelanggan menjadi harmonis dan memberikan kesan yang baik kepada pelanggan untuk pembelian ulang sehingga terciptanya loyalitas pelanggan serta rekomendasi dari mulut ke mulut terhadap suatu barang atau jasa yang menguntungkan bagi perusahaan.

Kepuasan pelanggan menurut Kotler dan Keller (2007), mengatakan bahwa kepuasan konsumen "adalah perasaan senang atau kecewa seseorang yang muncul setelah membandingkan kinerja (hasil) produk yang dipikirkan terhadap kinerja yang diharapkan".

Kepuasan pelanggan ditentukan oleh kualitas barang dan jasa yang dikehendaki oleh pelanggan sehingga jaminan kualitas produk menjadi prioritas uatama bagi setiap perusahaan yang pada saat ini khususnya dijadikan sebagai tolak ukur keunggulan daya saing perusahaan. Kualitas produk yang baik adalah produk yang diberikan pelanggan lebih baik atau lebih tinggi kualitasnya dibandingkan 
pesaingnya. Cara mencapainya adalah dengan memenuhi atau bahkan melampaui kualitas produk yang diharapkan oleh para pelanggan.

Kualitas produk menurut Kotler dan Keller (2007) produk adalah "Segala sesuatu yang dapat ditawarkan kedalam pasar untuk diperhatikan, dimiliki, dipakai atau dikonsumsi sehingga dapat memuaskan suatu keinginan/semua kebutuhan".

Perusahaan jasa kontraktor sendiri tentunya harus juga dapat mempertahankan atau terus meningkatkan kreatifitas agar pelanggan tidak menggunakan jasa perusahaan lain. Salah satu untuk mempertahankan pelanggan agar tidak menggunakan jasa perusahaan lain adalah dengan cara menciptakan suatu kepuasan pelanggan.

Seperti halnya perusahaanperusahaan yang sejenis saling mengungguli dan saling mengembangkan hasil produknya dengan harapan dapat memberikan kepuasan kepada pelanggan maka untuk menghadapi masalah ini tidak ada jalan lain, selain meningkatkan usaha di bidang pemasaran. Salah satu tindakan dalam pemasaran guna untuk mendapatkan kepuasan pelanggan adalah meningkatkan kualitas pelayanan.

Kualitas layanan menurut Tjiptono, 2008, "sebagai upaya pemenuhan kebutuhan dan keinginan pelanggan serta ketepatan penyampaiannya dalam mengimbangi harapan pelanggan". Kualitas layanan dapat diketahui dengan cara membandingkan persepsi para pelanggan atas layanan yang nyata-nyata mereka terima/peroleh dengan layanan yang sesungguhnya mereka harapkan/inginkan terhadap atributatribut layanan suatu perusahaan. Jika jasa yang diterima atau dirasakan sesuai dengan yang diharapkan, maka kualitas layanan dipersepsikan baik dan memuaskan, jika jasa yang diterima melampaui harapan pelanggan, maka kualitas layanan dipersepsikan sangat baik dan berkualitas. Sebaliknya jika jasa yang diterima lebih rendah daripada yang diharapkan, maka kualitas layanan dipersepsikan buruk.

Perwujudan kualitas jasa yang dilakukan oleh suatu perusahaan yang bergerak di bidang jasa adalah dengan memberikan kualitas layanan yang terbaik bagi pelanggan dengan tujuan untuk menciptakan kepuasan pelanggan. Kualitas yang diberikan oleh perusahaan, akan menimbulkan persepsi pelanggan terhadap kualitas yang diberikan kepadanya. Sering kali terdapat perbedaan antara harapan pelanggan dengan persepsi pelanggan terhadap kualitas yang diberikan oleh perusahaan. Untuk mengetahui apakah perusahaan telah memberikan kualitas jasa yang sesuai dengan harapan pelanggan, maka perlu dilakukan evaluasi dari pelanggannya.

PT. Azbil Berca Indonesia merupakan perusahaan yang bergerak dalam bidang jasa building automatic system yaitu membangun sistem otomatik seperti gedung perkantoran, pabrik, hotel, rumah sakit dan fasilitas umum, yang senantiasa berusaha melakukan kegiatannya agar tetap eksis dengan memberikan layanan yang terbaik kepada pelanggan sehingga pelanggan merasa puas.

Untuk mempertahankan dan meningkatkan kepuasan para pelanggan yang telah menggunakan jasa building automatic system dengan meningkatkan kualitas layanan yang baik dan tepat.

Kualitas layanan merupakan aspek penting bagi sebuah perusahaan jasa building automatic system seperti PT. Azbil Berca Indonesia karena pada dasarnya produk dan layanan yang ditawarkan oleh perusahaan jasa building automatic system PT. Azbil Berca Indonesia itu sendiri adalah kualitas produk dan layanan jasa terutama jasa pemasangan building automatic system kepada pelanggan. 
Tujuan penelitian ini adalah untuk mengetahui "Pengaruh Kualitas Produk dan Kualitas Layanan Terhadap Kepuasan Pelanggan Dalam Menggunakan Jasa Building Automatic System PT. Azbil Berca Indonesia”.

\section{LANDASAN TEORI}

\section{Kualitas Produk}

Produk memiliki arti penting bagi perusahaan karena tanpa adanya produk, perusahaan tidak akan dapat melakukan apapun dari usahanya. Pembeli akan membeli produk kalau merasa cocok, karena itu produk harus disesuaikan dengan keinginan ataupun kebutuhan pembeli agar pemasaran produk berhasil. Dengan kata lain, pembuatan produk lebih baik diorientasikan pada keinginan pasar atau selera konsumen.

Menurut Kotler dan Keller (2007) kualitas produk adalah "keseluruhan ciri serta dari suatu produk atau pelayanan pada kemampuan untuk memuaskan kebutuhan yang dinyatakan/ tersirat". Sedangkan menurut Schiffman dan Kanuk (2009), kualitas produk adalah "kemampuan suatu perusahaan untuk memberikan identitas atau ciri pada setiap produknya sehingga konsumen dapat mengenali produk tersebut". Selanjutnya menurut

Perreault, Cannon dan McCarthy (2010) mengemukakan bahwa, "Produk merupakan hasil dari produksi yang akan dilempar kepada konsumen untuk didistribusikan dan dimanfaatkan konsumen untuk memenuhi kebutuhannya".

Dimensi kualitas produk menurut Tjiptono (2008) adalah sebagai berikut: 1) "Kinerja, merupakan karakteristik operasi dan produk inti yang dibeli. Misalnya kecepatan, kemudahan dan kenyamanan dalam penggunaan. 2) Daya tahan, yang berarti daya tahan menunjukan usia produk, yaitu jumlah pemakaian suatu produk sebelum produk itu digantikan atau rusak. Semakin lama daya tahannya tentu semakin awet, produk yang awet akan dipersepsikan lebih berkualitas dibanding produk yang cepat habis atau cepat diganti. 3) Kesesuaian dengan spesifikasi, yaitu kesesuaian yaitu sejauh mana karakteristik desain dan operasi memenuhi standar yang telah ditetapkan sebelumnya. Misalnya pengawasan kualitas dan desain, Standar karakteristik operasional adalah kesesuaian kinerja produk dengan standar yang dinyatakan suatu produk. Ini semacam "janji" yang harus dipenuhi oleh produk. Produk yang memiliki kualitas dari dimensi ini berarti sesuai dengan standarnya. 4) Fitur, merupakan karakteristik atau ciri-ciri tambahan yang melengkapi manfaat dasar suatu produk. Fitur bersifat pilihan atau option bagi konsumen. Fitur bisa meningkatkan kualitas produk jika kompetitor tidak memiliki fitur tersebut. 5) Reliabilitas, yaitu kemungkinan kecil akan mengalami kerusakan atau gagal pakai. Misalnya pengawasan kualitas dan desain, standar karakteristik operasional kesesuaian dengan spesifikasi. 6) Estetika, yaitu daya tarik produk terhadap panca indera, misalkan bentuk fisik, model atau desain yang artistik, warna dan sebagainya. 7) Kesan kualitas, yaitu persepsi konsumen terhadap keseluruhan kualitas atau keunggulan suatu produk. Biasanya karena kurangnya pengetahuan pembeli akan atribut atau ciri-ciri produk yang akan dibeli, maka pembeli mempersepsikan kualitasnya dari aspek harga, nama merek, iklan, reputasi perusahaan, maupun negara pembuatnya. 8) Kemampuan produk, yaitu kualitas produk ditentukan atas dasar kemampuan diperbaiki: mudah, cepat, dan kompeten. Produk yang mampu diperbaiki tentu kualitasnya lebih tinggi dibandingkan dengan produk yang tidak atau sulit diperbaiki".

Berdasarkan definisi diatas produk dapat dikatakan sebagai fokus inti dari 
semua bisnis. Produk adalah apa yang dilakukan perusahaan, mulai dari mendesain, mengadakan sistem produksi dan operasi, menciptakan program pemasaran, sistem distribusi, iklan dan mengarahkan tenaga penjual untuk menjual produk tersebut.

Menurut Kotler dan Armstrong (2008) dalam merencanakan penawaran suatu produk, pemasar harus memahami lima tingkat produk, yaitu: 1) "Produk Utama, yaitu manfaat yang sebenarnya dibutuhkan dan akan dikonsumsi oleh pelanggan dari setiap produk. 2) Produk Generik, adalah produk dasar yang mampu memenuhi fungsi pokok produk yang paling dasar. 3) Produk Harapan, adalah produk formal yang ditawarkan dengan berbagai atribut dan kondisi secara normal (layak) diharapkan dan disepakati untuk dibeli. 4) Produk Pelengkap, adalah berbagai atribut produk yang dilengkapi atau ditambahkan dengan berbagai manfaat dan layanan, sehingga dapat memberikan tambahan kepuasan dan dapat dibedakan dengan produk pesaing. 5) Produk Potensial, adalah segala macam tambahan dan perubahan yang mungkin dikembangkan untuk suatu produk dimasa mendatang".

\section{Kualitas Layanan}

Kualitas layanan menjadi suatu keharusan yang harus dilakukan perusahaan agar dapat mampu bertahan dan tetap mendapat kepercayaan pelanggan. Pola konsumsi dan gaya hidup pelanggan menuntut perusahaan mampu memberikan layanan yang berkualitas. Menurut Berry dan Zenthaml yang dalam Lupiyoadi (2006) berpendapat bahwa "Keberhasilan perusahaan dalam memberikan layanan yang berkualitas dapat ditentukan dengan pendekatan service quality".

Service Quality adalah seberapa jauh perbedaan antara harapan dan kenyataan para pelanggan atas layanan yang mereka terima. Service Quality dapat diketahui dengan cara membandingkan persepsi pelanggan atas layanan yang benar-benar mereka terima dengan layanan sesungguhnya yang mereka harapkan. Kualitas layanan menjadi hal utama yang diperhatikan serius oleh perusahaan, yang melibatkan seluruh sumber daya yang dimiliki perusahaan.

Wyckof dalam Wisnalmawati (2005) berpendapat bahwa "Kualitas layanan adalah tingkat keunggulan yang diharapkan dan pengendalian atas tingkat keunggulan untuk memenuhi keinginan pelanggan". Apabila layanan yang diterima sesuai dengan yang diharapkan, maka kualitas layanan dipersepsikan baik dan memuaskan. Tjiptono (2008) menerangkan bahwa "apabila layanan yang diterima melebihi harapan pelanggan, maka kualitas layanan dipersepsikan ideal. Jika layanan yang diterima lebih rendah dari pada yang diharapkan, maka kualitas layanan dianggap buruk".

Apabila layanan yang diterima atau dirasakan sesuai dengan harapan pelanggan, maka kualitas yang diterima atau dirasakan sesuai dengan harapan pelanggan, maka kualitas layanan dipersepsikan sebagai kualitas ideal, tetapi sebaliknya jika layanan yang diterima atau dirasakan lebih rendah dari yang diharapkan maka kualitas layanan dipersepsikan rendah.

Unsur-unsur kualitas layanan yang dikutip dalam Saleh (2010) antara lain adalah: 1) "Penampilan; Personal dan fisik sebagaimana layanan kantor depan memerlukan persyaratan seperti berpenampilan menarik, badan harus tegap/tidak cacat, tutur bahasa menarik, familiar dalam berperilaku, penampilan penuh percaya diri. 2) Tepat Waktu dan Janji; Secara utuh dan prima petugas pelayanan dalam menyampaikan perlu diperhitungkan janji yang disampaikan kepada pelanggan bukan sebaliknya 
selalu ingkar janji. Demikian juga waktu jika mengutarakan 2 hari selesai harus betul-betul dapat memenuhinya. 3) Kesediaan Melayani; Sebagiamana fungsi dan wewenang harus melayani kepada para pelanggan, konsekuensi logis petugas harus benar-benar bersedia melayani kepada para pelanggan. 4) Pengetahuan dan Keahlian; Sebagai syarat untuk melayani dengan baik, petugas harus mempunyai pengetahuan dan keahlian. Di sini petugas pelayanan harus memiliki tingkat pendidikan tertentu dan pelatihan tertentu yang diisyaratkan dalam jabatan serta memiliki pengalaman yang luas dibidangnya. 5) Kesopanan dan Ramah Tamah; Masyarakat pengguna jasa pelayanan itu sendiri dan lapisan masyarakat baik tingkat status ekonomi dan sosial rendah maupun tinggi terdapat perbedaan karakternya maka petugas pelayanan masyarakat dituntut adanya keramahtamahan yang standar dalam melayani, sabar, tidak egois dan santun dalam bertutur kepada pelanggan. 6) Kejujuran dan Kepercayaan; Pelayanan ini oleh pengguna jasa dapat dipergunakan berbagai aspek, maka dalam penyelenggaraannya harus transparan dari aspek kejujuran, jujur dalam bentuk aturan, jujur dalam pembiayaan dan jujur dalam penyelesaian waktunya. Dari aspek kejujuran ini petugas pelayanan tersebut dapat dikategorikan sebagai pelayan yang dipercaya dari segi sikapnya, dapat dipercaya dari tutur katanya, dapat dipercayakan dalam menyelesaikan akhir pelayanan sehingga otomatis pelanggan merasa puas. Unsur pelayanan prima dapat ditambah unsur yang lain. 7) Kepastian Hukum; Secara sadar bahwa hasil pelayanan terhadap masyarakat yang berupa surat keputusan, harus mempunyai legitimasi atau mempunyai kepastian hukum. Bila setiap hasil yang tidak mempunyai kepastian hukum jelas akan mempengaruhi sikap masyarakat, misalnya pengurusan KTP, KK dan lainlain bila ditemukan cacat hukum akan mempengaruhi kredibilitas instansi yang mengeluarkan surat legitimasi tersebut. 8) Keterbukaan; Secara pasti bahwa setiap urusan/kegiatan yang memperlakukan ijin, maka ketentuan keterbukaan perlu ditegakkan. Keterbukaan itu akan mempengaruhi unsur-unsur kesederhanaan, kejelasan informasi kepada masyarakat. 9) Efisien; Dari setiap pelayanan dalam berbagai urusan, tuntutan masyarakat adalah efisiensi dan efektifitas dari berbagai aspek sumber daya sehingga menghasilkan biaya yang murah, waktu yang singkat dan tepat serta kualitas yang tinggi. Dengan demikian efisiensi dan efektifitas merupakan tuntutan yang harus diwujudkan dan perlu diperhatikan secara serius. 10) Biaya; Pemantapan pengurusan dalam pelayanan diperlukan kewajaran dalam penentuan pembiayaan, pembiayaan harus disesuaikan dengan daya beli masyarakat dan pengeluaran biaya harus transparan dan sesuai dengan ketentuan peraturan perundangundangan. 11) Tidak Rasial; Pengurusan pelayanan dilarang membeda-bedakan kesukuan, agama, aliran dan politik dengan demikian segala urusan harus memenuhi jangkauan yang luas dan merata. 12) Kesederhanaan; Prosedur dan tata cara pelayanan kepada masyarakat untuk diperhatikan kemudahan, tidak berbelit-belit dalam pelaksanaan".

$$
\text { Menurut Kotler }
$$

menyebutkan lima dimensi kualitas layanan yang harus dipenuhi yaitu: 1) "Bukti fisik, yaitu penampilan fisik layanan persuahaan, seperti penampilan fasilitas fisik, peralatan, personel, kebersihan, kerapihan dan media komunikasi. 2) Empati, yaitu kesediaan karyawan dan pengusaha untuk lebih peduli memberikan perhatian secara pribadi kepada pelanggan. 3) Kehandalan, yaitu kemampuan perusahaan untuk melaksanakan jasa 
yang dijanjikan dengan tepat dan terpecaya. 4) Cepat tanggap, yaitu daya tanggap perusahaan dalam memberikan layanan bagi pelanggan dan memberikan jasa dengan sigap dan cepat dalam melayani menangani transaksi dan penanganan keluhan pelanggan. 5) Jaminan, yaitu kemampuan perusahaan memberi jaminan pelayanan yang merupakan pengetahuan dan kesopanan karyawan serta kemampuan mereka untuk menimbulkan kepercayaan dan keyakinan".

\section{Kepuasan Pelanggan}

Kepuasan pelanggan menurut Amir (2005), adalah "sejauh mana manfaat sebuah produk dirasakan sesuai dengan apa yang diharapkan pelanggan". Kepuasan konsumen menurut Supranto (2011) adalah "perbedaan antara harapan dan kinerja yang dirasakan. Jadi, kinerja suatu barang sekurang-kurangnya sama dengan yang diharapkan". Sedangkan menurut Tjiptono (2015) kepuasaan pelanggan adalah "rasa nyaman konsumen ketika mendapatkan hasil produk yang dipilih berkualitas lebih baik daripada hasil produk yang tidak dipilih dengan kualitas buruk atau lebih buruk".

Dari definisi - definisi tersebut dapat dilihat kesamaan bahwa kepuasan pelanggan merupakan suatu perasaan atau penilaian emosional dari pelanggan atas penggunaan produk barang atau jasa ketika harapan dan kebutuhan terpenuhi dengan kata lain, jika pelanggan merasa apa yang diperoleh lebih rendah dari yang diharapkan maka pelanggan tersebut tidak puas. Jika apa yang diperoleh pelanggan sama dengan apa yang diharapkan maka pelanggan akan puas, jika apa yang diperoleh pelanggan melebihi apa yang diharapkan maka pelanggan akan merasa sangat puas.

Menurut Lupiyoadi (2013), ada lima faktor yang harus diperhatikan oleh perusahaan dalam menentukan tingkat kepuasan pelanggan, diantaranya sebagai berikut: 1) "Kualitas produk, pelanggan akan merasa puas bila hasil evaluasi (setelah membeli dan menggunakan produk) mereka menunjukkan bahwa produk yang mereka gunakan berkualitas). 2) Kualitas layanan, pelanggan akan merasa puas bila mereka mendapatkan layanan yang baik atau sesuai dengan yang diharapkannya baik dari segi kualitas layanan maupun kecepatan layanan. 3) Emosional, perasaan pelanggan merasa bangga dan mendapatkan keyakinan bahwa orang lain kagum kepadanya bila ia memakai produk dengan merek tertentu. 4) Harga, penetapan harga pada sebuah produk perusahaan sesuai dengan kualitas dan kuantitas produk yang didapat dan diharapkan oleh pelanggan. 5) Biaya dan kemudahan dalam mendapat produk/jasa, oelanggan tidak perlu mengeluarkan biaya tambahan atau membuang waktu untuk mendapatkan suatu produk cenderung puas terhadap produk dan kemudahan dalam mendapatkan produk".

Hawkins dan Lonney dikutip dalam Tjiptono (2008) indikator pembentuk kepuasan terdiri dari: 1) "Kesesuaian harapan, merupakan tingkat kesesuaian antara kinerja produk yang diharapkan oleh pelanggan dengan yang dirasakan oleh pelanggan, meliputi : a) Produk yang diperoleh sesuai atau melebihi dengan yang diharapkan. b) Layanan oleh karyawan yang diperoleh sesuai atau melebihi dengan yang diharapkan. c) Fasilitas penunjang yang didapat sesuai atau melebihi dengan yang diharapkan. 2) Minat berkunjung kembali, merupakan kesedian pelanggan untuk berkunjung kembali atau melakukan pembelian ulang terhadap produk terkait, meliputi: a) Berminat untuk berkunjung kembali karena pelayanan yang diberikan oleh karyawan memuaskan. b) Berminat untuk berkunjung kembali karena nilai dan manfaat yang diperoleh setelah mengkonsumsi produk. c) Berminat 
untuk berkunjung kembali karena fasilitas penunjang yang disediakan memadai. 3 ) Kesediaan merekomendasikan, merupakan kesediaan pelanggan untuk merekomendasikan produk yang telah dirasakannya kepada teman atau keluarga, meliputi: a) Menyarankan teman atau kerabat untuk membeli produk yang ditawarkan karena pelayanan yang memuaskan. b) Menyarankan teman atau kerabat untuk membeli produk yang ditawarkan karena fasilitas penunjang yang disediakan memadai. c) Menyarankan teman atau kerabat untuk membeli produk yang ditawarkan karena nilai atau manfaat yang didapat setelah mengkonsumsi sebuah produk jasa.

\section{METODE PENELITIAN}

Metode penelitian yang digunakan adalah metode penelitian kuantitatif dengan jumlah sampel 30 perusahaan. Data dikumpulkan dengan menggunakan metode kuesioner, uji instrumen data, dan teknik analisis data yang digunakan adalah analisis regresi linier berganda, korelasi ganda dan koefisien determinasi.

\section{HASIL PENELITIAN}

\section{Uji Instrumen Data}

Tabel 1. Hasil Uji Validitas Instrumen Data

\begin{tabular}{|c|c|c|c|c|c|}
\hline \multirow[b]{2}{*}{ Pernyataan } & \multicolumn{3}{|c|}{ R hitung } & \multirow[b]{2}{*}{$\underset{\text { kritis }}{R}$} & \multirow[b]{2}{*}{ Kesimpulan } \\
\hline & $\begin{array}{l}\text { Kualitas } \\
\text { Produk }\end{array}$ & $\begin{array}{l}\text { Kualitas } \\
\text { Layanan }\end{array}$ & $\begin{array}{l}\text { Kepuasan } \\
\text { Pelanggan }\end{array}$ & & \\
\hline Butir 1 & 0,598 & 0,439 & 0,793 & 0,300 & Valid \\
\hline Butir 2 & 0,666 & 0,560 & 0,749 & 0,300 & Valid \\
\hline Butir 3 & 0,661 & 0,540 & 0,693 & 0,300 & Valid \\
\hline Butir 4 & 0,630 & 0,444 & 0,677 & 0,300 & Valid \\
\hline Butir 5 & 0,658 & 0,588 & 0,723 & 0,300 & Valid \\
\hline Butir 6 & 0,502 & 0,462 & 0,510 & 0,300 & Valid \\
\hline Butir 7 & 0,710 & 0,495 & 0,791 & 0,300 & Valid \\
\hline Butir 8 & 0,808 & 0,470 & 0,679 & 0,300 & Valid \\
\hline Butir 9 & 0,527 & 0,483 & 0,783 & 0.300 & Valid \\
\hline Butir 10 & 0 & 0,399 & 0 & 0,300 & Valid \\
\hline
\end{tabular}

Sumber: data diolah tahun 2018 
Berdasarkan Tabel 1, dapat dilihat bahwa dari 9 butir pernyataan dari variabel kualitas produk, 10 pernyataan kualitas layanan dan 9 pertanyaan kepuasan pelanggan hasilnya adalah valid.

\section{Uji Reliabiltas}

\begin{tabular}{|c|c|c|c|}
\hline Variabel & $\begin{array}{c}\text { Cronbach } \\
\text { Alpha }\end{array}$ & $\begin{array}{c}\text { Nilai kritis } \\
(\alpha)=5 \%\end{array}$ & Keterangan \\
\hline Kualitas Produk & 0.816 & 0.600 & Reliabel \\
\hline Kualitas Layanan & 0.856 & 0.600 & Reliabel \\
\hline Kepuasan Pelanggan & 0.874 & 0.600 & Reliabel \\
\hline
\end{tabular}

Berdasarkan angka-angka reliabilitas cronbach alpha tersebut tampak bahwa seluruh pernyataan yang ada membentuk ukuran yang reliabel

\section{Analisa Hasil Penelitian}

Tabel 3. Pengaruh Kualitas Produk dan Kualitas Layanan Terhadap Kepuasan Pelanggan PT. Azbil Berca Indonesia

\begin{tabular}{|c|c|c|c|c|c|c|}
\hline \multirow{2}{*}{$\begin{array}{c}\text { Hubungan } \\
\text { Variabel }\end{array}$} & \multicolumn{6}{|c|}{ Parameter } \\
\hline & $\begin{array}{c}\text { Mult. } \\
\text { R }\end{array}$ & $\begin{array}{c}\mathbf{R} \\
\text { Square }\end{array}$ & $\begin{array}{l}\text { Kons } \\
\text { tanta }\end{array}$ & Coef. B & Sig & $\boldsymbol{\alpha}$ \\
\hline $\begin{array}{l}\text { Kualitas } \\
\text { Produk }\end{array}$ & \multirow{2}{*}{0.869} & \multirow{2}{*}{0.755} & \multirow{2}{*}{0.520} & 0.579 & \multirow{2}{*}{0.000} & \multirow[b]{2}{*}{$5 \%$} \\
\hline $\begin{array}{l}\text { Kualitas } \\
\text { Layanan }\end{array}$ & & & & 0.392 & & \\
\hline \multicolumn{7}{|c|}{ Pengujian Signifikan } \\
\hline \multicolumn{7}{|c|}{ F hitung $>$ F Tabel $=41.551>3.354$} \\
\hline
\end{tabular}

Dari hasil Tabel 3 Koefisien regresi secara simultan diperoleh persamaan regresi yaitu sebesar $\hat{Y}=0,520+$ $0,579\left(\mathrm{X}_{1}\right)+0,392\left(\mathrm{X}_{2}\right)$. Dari persamaan regresi berganda (bersama-sama) dapat dilihat arah hubungan yang dihasilkan dari variabel bebas terhadap variabel terikatnya, yaitu: 1) Pengujian hubungan simultan kualitas produk dan kualitas layanan terhadap kepuasan pelanggan dalam menggunakan Jasa Building Automatic System PT. Azbil Berca Indonesia signifikan atau tidak, dilakukan pengujian $\mathrm{F}$ hitung dibandingkan $\mathrm{F}$ Tabel atau dengan tingkat Signifikansi $\mathrm{F}=$ kualitas produk, kualitas layanan dan kepuasan pelanggan membentuk ukuran yang reliabel dari masing-masing dimensi. reliabilitas untuk mengetahui sejauh mana hasil pengukurannya dapat diandalkan dan konsisten. Pada Tabel-2 hasil pengujian berikut diketahui bahwa semua variabel mempunyai alpha di atas 0.60 yang berarti bahwa semua variabel dalam penelitian ini dapat diandalkan.

uji . 
layanan, sedangkan sisanya yaitu $24,5 \%$ disumbangkan oleh faktor-faktor lainnya. 2) Koefisien regresi kualitas produk sebesar 0,579 mempunyai arti bahwa setiap peningkatan 1 kali kualitas produk, maka kepuasan pelanggan akan meningkat sebesar 0,579 satuan. 3) Koefisien regresi kualitas layanan sebesar 0,392 mempunyai arti bahwa setiap peningkatan 1 kali kualitas layanan, maka kepuasan pelanggan akan meningkat sebesar 0,392 .

\section{Pembahasan}

Dari hasil penelitian menunjukan bahwa adanya peningkatan kualitas produk diduga akan meningkatkan kepuasan pelanggan dalam menggunakan jasa building automatic system PT. Azbil Berca Indonesia. Hal ini dikarenakan pernyataan bahwa mudah dalam menggunakan produk MIS dan SCS, memiliki kecepatan yang optimal, mempunyai daya tahan yang lama produknya, sesuai dengan standar yang telah ditetapkan, memiliki karakteristik tambahan dalam melengkapi manfaat produk, kecil kemungkinan mengalami kerusakan atau gagal pakai, model artistik menjadi daya traik produk, pelanggan puas atas produk dan harga yang ditawarkan, dan produk MIS dan SCS mempunyai kualitas tinggi dan mudah diperbaiki.

Dari hasil penelitian menyatakan bahwa adanya peningkatan kualitas layanan diduga akan meningkatkan kepuasan pelanggan dalam menggunakan jasa building automatic system PT. Azbil Berca Indonesia. Hal ini dikarenakan pernyataan bahwa tempat ruang tunggu pelanggan bersih, nyaman dan sejuk, karyawan dalam bertugas memakai seragam yang rapi dan berpenampilan menarik, karyawan memberikan perhatian yang lebih pada pelanggan, perushaan memberikanjasa pelatihan pada pelanggan untuk menjalin hubungan, jasa yang dijanjikan dapat dipercaya, tepat waktu, perusahaan memberikan jasa layanan bagi pelanggan dengan sigap, dengan cepat dalam melayani keluhan pelanggan, memberikan jaminan layanan dapat dipercaya, dan pengetahuan serta kesopanan karyawan memberikan jaminan layanan dapat diyakini.

\section{KESIMPULAN DAN SARAN}

\section{Kesimpulan}

Berdasarkan uji simultan dari kualitas produk dan kualitas layanan terhadap kepuasan pelanggan dalam menggunakan jasa building automaatic system PT. Azbil Berca Indonesia, penelitian ini berhasil membuktikan bahwa: 1) Kualitas produk berpengaruh positif dan signifikan terhadap kepuasan pelanggan dalam menggunakan jasa building automaatic system PT. Azbil Berca Indonesia, artinya, PT. Azbil Berca Indonesia sangat menjaga kualitas produk dengan baik terbukti perusahaan selalu mengadakan pengecekan terhadap produk yang digunakan dan dipasang pada perusahaan pelanggan. dihasilkan. 2) Kualitas layanan berpengaruh positif dan signifikan terhadap kepuasan pelanggan dalam menggunakan jasa building automaatic system PT. Azbil Berca Indonesia, artinya, PT. Azbil Berca Indonesia selalu menjaga kepercayaan dan memberikan layanan yang terbaik buat para pelanggannya agar para pelanggan tidak lari dari PT. Azbil Berca Indonesia atau ke para pesaing yang lain. 3) Variabel kualitas produk adalah variabel yang dominan dalam mempengaruhi kepuasan pelanggan dalam menggunakan jasa building automaatic system PT. Azbil Berca Indonesia, sehingga PT. Azbil Berca Indonesia terus menjaga kualitas produk yang sudah dipakai oleh para pelanggannya, hal ini akan mempunyai pengaruh yang sangat tinggi bagi para pelanggan untuk tetap menggunakan 
jasa building automatic system PT. Azbil Berca Indonesia produk yang dihasilkan.

\section{Saran}

Berdasarkan penelitian ini, peneliti perlu memberikan beberapa saran yang dapat dipertimbangkan oleh PT, Azbil Berca Indonesia sebagai upaya pencapaian tujuan perusahaan adalah sebagai berikut: 1) Dari hasil penelitian yang telah dilakukan di dalam PT. Azbil Berca Indonesia, tetap mempertahankan dan meningkatkan kualitas produk yang sudah diberikan kepada pelanggan dan kualitas layanan tetap dijaga dan dipertahankan, mengingat para pelanggan sudah sangat harmonis dalam menjalin hubungan, berikan layanan yang lebih baik lagi agar pelanggan tetap mempercayai PT. Azbil Berca Indonesia sebagai patner kerja. 2) peneliti, menyarankan kepada PT. Azbil Berca Indonesia untuk terus melakukan evaluasi produk-produk yang sudah dipakai oleh pelanggan untuk dapat bersaing dengan para perusahaan jasa building automatic yang lain.

\section{DAFTAR PUSTAKA}

Amir, M. Taufiq. 2005. Dinamika Pemasaran: Jelajahi \& Rasakan. Jakarta: Raja Grafindo. Persada.

Berry, L. L., Parasuraman, A., \& Zeithaml, V. A. 2001. Service Quality Can Often Make The Difference Between a Business's Success and Failure. But What Causes Problems, and What Can Business Do To Eliminate Them? The Answers Are Here. Journal of Marketing, 35-43.

Ghozali, Imam. 2016. Aplikasi Analisis Multivariete: Dengan Program IBM SPSS 23. Semarang. Badan Penerbit Universitas Diponegoro.

Hawkins, Del. I dan Lonney Coney. 1997. Consumer Behaviour:
Building Marketing Strategy. New York: McGraw-Hill.

Jr., William D. Perreault, Joseph P. Cannon dan E. Jerome McCarthy. 2010. Basic Marketing: A Marketing Strategy Planning Approach, $18^{\text {th }}$ Edition. New York: McGraw Hill.

J. Supranto. 2011. Pengukuran Tingkat Kepuasan Pelanggan : Untuk Menaikkan Pangsa Pasar. Jakart. Penerbit Rineka Cipta

Kotler, Philip. 2006. Manajemen Pemasaran, Jilid 1, Jakarta. Penerbit PT. Indeks.

Kotler, Philip dan Kevin Lane Keller. 2007. Manajemen Pemasaran, Jilid 1, Edisi 12. Jakarta. Penerbit Indeks.

Kotler, Philip dan Gary Armstrong. 2008. Prinsip-Prinsip Pemasaran, Jilid 1, Edisi 12. Jakarta. Penerbit Erlangga.

Lupiyoadi, Rambat \& A. Hamdani. 2006. Manajemen Pemasaran Jasa, Edisi 2. Jakarta. Penerbit Salemba Empat.

Lupiyoadi, Rambat.2013. Manajemen Pemasaran Jasa. Jakarta. Penerbit Salemba Empat

Noor, Juliansyah. 2014. Metodologi Penelitian: Skripsi, Tesis, Disertasi, \& Karya Ilmiah. Jakarta. Penerbit Kencana.

Riduwan \& Sunarto. 2011. Pengantar Statistika untuk Penelitian : Pendidikan, Sosial, Komunikasi, Ekonomi dan Bisnis. Bandung. Penerbit Alfabeta.

Saleh, Akh. Muwafik. 2010. Manajemen Pelayanan. Jakarta. Penerbit Pustaka Pelajar.

Santoso, Singgih. 2010. Statistik Multivariat dengan SPSS. Jakarta. Penerbit PT. Elex Media Komputindo.

Sugiyono. 2016. Statikstika Untuk Penelitian. Bandung. Penerbit Alfabeta. 
Tjiptono, Fandy. 2008. Total Quality Management (TQM), Edisi 5. Yogyakarta. Penerbit Andy Offset

Tjiptono, Fandy. 2015. Strategi Pemasaran. Edisi 4. Yogyakarta. Penerbit Andy Offset.

Wisnalmawati. 2005. "Pengaruh Persepsi Dimensi Kualitas Layanan
Terhadap Niat Pembelian Ulang”. Jurnal Ekonomi dan Bisnis, No. 3, Jilid 10, h. 153-165.

Wyckof. 2002. Prinsip Pemasaran, Edisi Ketujuh, Jilid I. Jakarta: Penerbit Erlangga 